\title{
The UK Domestic Gas Electricity (Tariff Cap) Act: Re-regulating the Retail Energy
}

\author{
Market
}

The UK retail energy market has witnessed multiple regulatory interventions since its liberalisation almost two decades ago. Such interventions reached their peak with the enactment of the UK Domestic Gas Electricity (Tariff Cap) Act in July 2018. The Act puts in place a requirement on the independent regulator, the Office of Gas and Electricity Markets (Ofgem), to set an absolute price cap on poor value tariffs. As such, it signals a repudiation of the overarching paradigm of consumer empowerment that has informed regulatory remedies to date. Rather than advocating for a different paradigm, this article highlights the difficulties inherent in reconciling price caps - both practically and conceptually - with the competitive process and consumer empowerment. It further brings to the fore other instruments, not necessarily exhausted in retail price regulation, that can render affordable energy prices, without sacrificing consumer empowerment.

Keywords: price caps, retail energy market, competition, regulation, consumer empowerment, consumer protection

\section{Introduction}

Very few sectors have witnessed such heated political debates in recent years as the UK liberalised retail energy market, and understandably so. The provision of energy supply is an essential service, crucial for societal cohesion. Yet, the retail energy market has been failing consumers. Household energy bills have increased in recent years, raising concerns in relation to energy affordability, especially for low-income consumers. ${ }^{1}$ It should, therefore, come as no surprise that the energy market has re-entered so dramatically the political battlefield. From Ed Miliband's promise of an 'energy price freeze' in $2013^{2}$ to

\footnotetext{
1 Ofgem, 'State of the Energy Market' (2017) 7 available at <https://www.ofgem.gov.uk/system/files/docs/2017/10/state_of the market_report 2017_web_1.pdf > (last accessed 12 June 2018).

${ }^{2}$ E. Miliband, 'Labour would freeze energy prices' (24th September 2013), <http://www.bbc.co.uk/news/ukpolitics-24213366> (last accessed 12 June 2018). For a criticism see C. Waddams, 'Price Regulation is not the Solution to Unaffordable Energy Prices' (CCP Blog post 2013) available at $<$ https://competitionpolicy.wordpress.com/2013/09/25/price-regulation-is-not-the-solution-to-unaffordableenergy-prices/> (last accessed 12 June 2018).
} 
the 2017 manifestos of both the UK Conservative and Labour parties, ${ }^{3}$ interventionist measures seeking to address the level of retail energy prices have resurfaced, despite ambitions that retail energy liberalisation would reduce state interference in the energy market. ${ }^{4}$

Such an interventionist appetite reached its peak with the adoption of the UK Domestic Gas and Electricity (Tariff Cap) Act (Tariff Cap Act), ${ }^{5}$ which is the focus of this article. In particular, the Act puts in place a requirement on the independent regulator, the Office of Gas and Electricity Markets (Ofgem), to set an absolute price cap on poor value tariffs, that is standard variable (SVTs) and default tariffs. ${ }^{6}$ An absolute cap requires the regulator to set a rate above which no energy supplier can charge. It is estimated that this price cap will protect around 11 million households in England, Wales and Scotland, who are currently on poor value tariffs. This in on top of already implemented price cap that protects 5 million consumers on prepayment meters and the, so-called, Warm House Discount that provides rebates on electricity bills for those consumers at risk of fuel poverty. ${ }^{7}$ It will be designed and delivered by Ofgem and apply until the end of 2020, when the regulator will recommend to the government whether it should be extended on an annual basis up to $2023 .^{8}$

One of the underlying rationales for the introduction of the Act has been the crude realisation that a significant number of consumers do not engage with the market and therefore have not been able to reap the benefits of competition, in terms of lower prices and better services. Those consumers who lose from the competitive process may not be 'empowered' to engage with the market and switch to better deals and/or may be

3 See 'The Conservative and Unionist Party Manifesto 2017' available at: https://www.conservatives.com/manifesto and 'The Labour Party Manifesto 2017' available at <https://labour.org.uk/wp-content/uploads/2017/10/labour-manifesto-2017.pdf> (last accessed 12 June 2018).

${ }^{4}$ T. Prosser, Nationalised Industries and Public Control (Oxford: Blackwell, 1986).

5 Domestic Gas and Electricity (Tariff Cap) Act 2018 (c. 21) available at <http://www.legislation.gov.uk/ukpga/2018/21/contents/enacted/data.htm> (accessed 30 July 2018).

${ }^{6}$ SVTs are the suppliers' default tariffs charged when consumers do not choose a specific price plan. They are normally higher than fixed tariffs, which offer guaranteed prices for the duration of the supply contract.

${ }^{7}$ Department of Business, Energy and Industrial Strategy (BEIS), 'New legislation to cap poor value energy tariffs and save consumers money is being introduced to Parliament later today' (26 February 2018) (Press Release) available at <https://www.gov.uk/government/news/government-introduces-new-legislation-tocap-poor-value-energy-tariffs-in-time-for-next-winter> (accessed 30 July 2018).

${ }^{8}$ Ibid. 
'vulnerable', and thus not 'protected' enough. It has always been difficult to distinguish between these two categories, not least because, as we shall see in Section III, disengaged consumers often exhibit characteristics of vulnerability. Whatever the underlying reasons for the apparent consumer disengagement with the marketplace, the result has been the same; energy firms have been exploiting 'losers' through their practices. This was starkly illustrated in the in-depth energy market investigation undertaken by the UK Competition and Markets Authority (CMA) that paved the way for the Tariff Cap Act. ${ }^{9}$ The CMA found, inter alia, that lack of consumer engagement with the energy market gave suppliers market power over the inactive body of customers, which suppliers were then able to exploit through their pricing practices. ${ }^{10}$ The CMA's findings were echoed in the Department for Business, Energy and Industrial Strategy (BEIS) Select Committee's pre-legislative scrutiny of the draft Tariff Cap Bill stating that:

[t]here is in effect a two-tier market in operation whereby active customers save money by switching suppliers, but those who can't or don't switch remain on poor value tariffs. It is of particular concern that customers who don't switch typically tend to be more vulnerable than those who are getting the best deals. The difference between the cheapest available tariff and the average Standard Variable Tariff of a Big 6 supplier is around $£ 300 .^{11}$

This 'two-tier market' consists of active consumers, who are able to access, assess and act upon the information provided to switch to better deals, and passive consumers, who 'can't or don't' switch and end up paying higher prices. In a sense, this pattern is not unique to energy. All liberalised markets create 'winners' and 'losers', from telecoms to financial services. ${ }^{12}$ However, energy supply is particularly salient, especially to low-income households, as poorer consumers may end up paying more as a proportion of the household

9 See CMA, 'Energy Market Investigation: Final Report' (24 June 2016) available at: $<$ https://assets.publishing.service.gov.uk/media/5773de34e5274a0da3000113/final-report-energy-marketinvestigation.pdf> (last accessed 12 June 2018).

${ }^{10}$ Ibid, para. 158.

11 BEIS, Energy: Written Statement (26 February 2018) available at $<$ https://www.parliament.uk/business/publications/written-questions-answers-statements/writtenstatement/Commons/2018-02-26/HCWS484/> (last accessed 12 June 2018).

${ }^{12}$ Similar concerns have been raised in banking and insurance, see CMA's report on the retail banking market investigation available <https://assets.publishing.service.gov.uk/media/57ac9667e5274a0f6c00007a/retail-banking-marketinvestigation-full-final-report.pdf> (last accessed 12 June 2018). 
income than wealthy ones, who consume greater energy quantities. ${ }^{13}$ Given the above, can such a 'two-tier' market be tolerated in services so essential to well-being and societal cohesion? Whilst there is little disagreement that the latter cannot be the case, there is much disagreement, however, regarding the appropriate remedy.

At the heart of these debates lies the normative interplay between consumer empowerment and consumer protection that transcends much of the post-financial crisis scholarly and regulatory debates on liberalised markets. ${ }^{14}$ Simply put, should those consumers who lose from the competitive process be empowered to engage with the market and search for better deals or should they be protected? The Tariff Cap Act clearly favours consumer protection over consumer empowerment to address the 'losers' of the competitive process. In other words, the proposed energy price cap should be understood as a paradigmatic example of a consumer protection measure implemented through state intervention in retail price setting and informed by affordability considerations. Consumer empowerment measures, that aim to enable consumer participation in the market, through the provision of information or otherwise, are closely associated with the overarching competition paradigm enshrined in the UK and the EU energy acquis and its underlying principle of economic efficiency. ${ }^{15}$ The competition paradigm prescribes that the price for the supply of energy should be the result of market forces and not set by the state - market forces being policed via the ex post application of competition law. Hence, the suggested price cap represents the most radical departure from the fundamental principle of marketbased retail energy price formation enshrined in the paradigm of competitive retail energy markets. Given the overarching competition and consumer empowerment objective, state

${ }^{13}$ C. Waddams Price, 'Back to the Future? Regulating Residential Energy Markets' (2018) 25 (1) International Journal of the Economics of Business 147, 148.

${ }^{14}$ See, for example, M.J. Trebilock, Dealing with Losers: The Political Economy of Policy Transitions (Oxford: OUP, 2015); W. Sauter, Public services in EU law (Cambridge: CUP, 2014); Commission (EU), 'Delivering a New Deal for Energy Consumers' (15 July 2015) COM(2015) 339 final (New Deal).

${ }^{15}$ Specifically, Article 3(1) of the Electricity Directive 2009/72/EC [O.J. 2009, L 211/55] and the Gas Directive 2009/73/EC [O.J. 2003, L 211/94] states that energy undertakings must be operated with a view to achieving a 'competitive market'. In the same vein, the EU Court of Justice has consistently held that the principle presumption of the rules on the internal energy market is the development and maintenance of competitive markets, see e.g. Case C-265/08, Federutility et al v Autorita per l'energia elettrica e il gas, EU:C:2010:205, paras. 18-19. The significance of the free operation of the market mechanism has been widely embraced by the EU Courts, which have highlighted that the EU energy acquis entails 'the freedom to determine the price for the supply of electricity', see e.g. See e.g. Case C-242/10, ENEL Produzione SpA $v$ Autorita per l'energia elettrica elettrica e il gas, EU:C:2011:861, para. 42. 
regulation of retail energy prices has been characterised an 'anachronism' 16 in the EU' liberalised retail energy market that should only be employed exceptionally for the protection of poor or vulnerable consumers. ${ }^{17}$

Drawing on our previous research, ${ }^{18}$ in this piece we argue that while affordable prices, such as the ones promised by the price cap, can directly protect vulnerable consumers, they do not provide a silver bullet for remedying what has become a 'two-tier' energy market. The price cap remedy provides only a quick fix for affordable energy supply, at the expense of strengthening consumer engagement with the energy market. This is owing to the fact that it has been advanced on the basis of a misguided understanding of the nature of consumer empowerment in the retail energy market. Consumer empowerment, we argue, encapsulates both the process of empowering consumers as well as the outcome of such process, i.e. the act of switching. The price cap remedy has been informed, however, solely by the 'outcome', namely the low switching rates, and has disregarded empowerment as a process. It, thus, wrongly prioritises equality of outcome rather than equality of opportunity in the market. We, then, highlight the unintended consequences of a short-term approach to consumer empowerment and explore alternative mechanisms for addressing consumer disengagement with the market, including less intrusive consumer protection instruments.

The argument is structured as follows. Section II provides a brief historical account of the UK retail energy market liberalisation, in order, first, to highlight the origins and evolution of the normative interplay between consumer empowerment and protection and second, to appreciate the drivers behind the enactment of the Tariff Cap Act. It will be argued that the price cap signals a repudiation of the overarching paradigm of consumer empowerment that is reflected in the EU and UK energy acquis ${ }^{19}$ and has informed regulatory remedies to date. Section III situates the price cap within the EU paradigm of consumer empowerment and discusses the difficulties surrounding its implementation. Section IV highlights the limits of the price cap in addressing consumer disengagement with the market and Section V concludes.

\footnotetext{
${ }^{16}$ See S. Fischerauer and A. Johnston, 'State Regulation of Retail Energy Prices: An Anachronism in the Liberalized EU Energy Market' (2016) 9 Journal of World Energy Law and Business 458.

${ }^{17}$ See Commission (EU), 'Proposal for a Directive of the European Parliament and of the Council on Common Rules for the Internal Market in Electricity' (recast) COM(2016) 864 final, Article 5(2)-(4).

18 Authors' names to be added in the final proofs.

${ }^{19}$ See, for example Annex 1 of the Electricity Directive 2009/72/EC and Gas Directive 2009/73/EC.
} 


\section{Setting the Scene: The Evolution of the UK Retail Energy Market and the 'Empowerment vs. Protection' Interplay}

The liberalisation of the retail energy market was predicated on the traditional economic assumption that encouraging competition contributes to lower prices and the promotion of consumer choice, thus safeguarding the interests of consumers. Central to this has been the neo-classical economics paradigm of a competitive market, according to which all market actors (producers and consumers) act in a rational manner that enables them to maximise their utility or profit. ${ }^{20}$ Within this paradigm, the promotion of consumer empowerment has both an intrinsic and an instrumental value; in a sense that well-informed, empowered consumers able to engage with the market and switch to better deals can better stimulate competition between energy suppliers and render 'efficient' prices. It will be shown throughout this section that, while in the early days of deregulation emphasis was placed on consumer protection measures-mostly enacted so as to address the limits of competition in catering for vulnerable consumers, consumer empowerment soon became increasingly prevalent as a regulatory goal. ${ }^{21}$ This increased emphasis on consumer empowerment was in turn the driving force behind a series of unsuccessful regulatory interventions, discussed below, that not only preceded but also paved the way for the Tariff Cap Act. The proposed price cap should therefore be properly understood as the last episode in a prolonged period of re-regulating the retail energy market to address concerns about the development of competition and the role of consumers therein.

\section{A. Regulating for Competition}

There was no competition for residential customers when the British energy supply market was privatised under the Gas Act 1986 and the Electricity Act 1989. Residential markets

\footnotetext{
${ }^{20}$ Neoclassical economics applies the tools of welfare economics to a benchmark based on perfect competition. It assumes, inter alia, many buyers and sellers none of which enjoys market power. This approach takes cost and demand curves as given and focuses on equilibrium where price equals marginal cost. See e.g. G. Mankiw \& M. Taylor, Economics (Hampshire, Cengage Learning EMEA, 3rd ed, 2014), ch. 3 .

${ }^{21}$ T. Prosser, The Limits of Competition Law: Markets and Public Services (Oxford: OUP, 2005).
} 
were first opened to competition between 1996 and 1999 by area for the gas monopoly, whereas liberalisation for the electricity market was introduced within region for each of the fourteen electricity regions. A single regulator, Ofgem, with oversight of both the gas and the electricity market was created from the merger of the Office of Gas Regulation (Ofgas) and the Office of Electricity Regulation (Offer) in 1999.

To protect consumers from potential abuse of monopoly power, the retail energy markets were subject to ex ante transitional price controls contained in the firms' licences, based on the RPI-X formula. ${ }^{22}$ But competition developed quickly. By 2002, the fourteen incumbent electricity suppliers had consolidated into five suppliers, largely separate from their previous distribution network businesses. Transitional price caps were completely lifted in April 2002, subjecting the pricing practices of firms to the provisions of the Competition Act 1998. ${ }^{23}$ By 2008, following subsequent consolidations, the original incumbents (Big Six) represented almost all the electricity and gas markets. ${ }^{24}$ Many energy firms entered the market from 2012 onwards, and hence in 2017 there were about 40 suppliers to the residential market. Notwithstanding this, the Big Six continued to supply around 82 per cent of households by March 2017. ${ }^{25}$

The removal of the price caps brought into greater focus the interplay between consumer empowerment and consumer protection that became firmly enshrined in the Utilities Act 2000. The Act gave Ofgem a new primary duty of protecting consumers 'wherever appropriate by promoting effective competition'. ${ }^{26}$ Hence, in 2003 Ofgem announced its Social Action Plan, a substantial programme for removing continuing obstacles to

\footnotetext{
${ }^{22}$ R. Baldwin, M. Cave and M. Loge, Understanding Regulation: Theory, Strategy and Practice (Oxford: OUP, 2nd ed, 2013) 70.

${ }^{23}$ s 45(1). The Competition Act 1998 includes provisions on the control of horizontal or vertical agreements, between two or more undertakings, for which provision is made in the prohibition of Chapter I. The Act covers also abuses committed by dominant firms (Chapter II prohibition).

${ }^{24}$ M. Hviid and C. Waddams Price, 'Non-discrimination Clauses in the Retail Energy Sector' (2012) 122 Economic Journal 236, 239; OFT, Ofgem, CMA, 'State of the Market Assessment' (27 March 2014), para. 2.6. The Big Six (Centrica, EDF, E.ON, RWE, SSE and Scottish Power) have approximately 95 per cent of supply and 70 per cent of the generation capacity. Ibid. para. 2.7.

25 Ofgem, 'Electricity Supply Market Shares by Company: Domestic (GB)' (2017) available at: https://www.ofgem.gov.uk/data-portal/electricity-supply-market-shares-company-domestic-gb $\quad$ (last accessed 30 July 2018); Ofgem, 'Gas Supply Market Shares by Company: Domestic (GB)' (2017) available at: https://www.ofgem.gov.uk/data-portal/gas-supply-market-shares-company-domestic-gb (last accessed 30 July 2018).

${ }^{26}$ Utilities Act, ss 13(1) and ss 9(1).
} 
competition and strengthening consumer choice and empowerment, by improving customer information and billing standards. ${ }^{27}$ At the same time, a new independent sectoral consumer body was created, Energywatch, which was given an overall consumer empowerment mandate, such as providing information on the market to consumers, as well as representing and championing their interests.

However, the promotion of competition was not intended to be a duty in itself, but a policy choice that would be adopted only 'where appropriate' to further the interests of consumers. Ofgem, therefore, also put in place a number of consumer protection measures to address the limits of competition. Some of these measures were predicated on its secondary duties to take into account the needs of low-income consumers, a group added to similar responsibilities previously held for those of pensionable age, the chronically sick and disabled and those in rural areas. ${ }^{28}$ Prior to liberalisation, such groups were served by ensuring universal access through uniform distribution charges within each area and crosssubsidisation, rather than on pricing which would reflect the costs of different consumer groups. Hence, consumers with higher than average costs (e.g. consumers in rural areas) were subsidised by those with lower costs (e.g. consumers in urban areas). Such uniform pricing could not be sustainable in a competitive environment, as it would encourage 'cream-skimming' from new entrants. In other words, new entrants would serve the lower cost consumers leaving the incumbent with the high cost consumers, who nobody wants to serve. Conscious of the distributional concerns brought forward by liberalisation, Ofgem further extended its Social Action Plan to ensure that the benefits of competition are extended to all customers, including prepayment meter customers, vulnerable customers, and the fuel poor.

\section{B. Re-regulating the Retail Energy Market: From the 2008 Energy Supply Probe to the 2017 UK Domestic Gas Electricity (Tariff Cap) Act}

27 Ofgem, 'Social Action Plan' (2003) available at <https://www.ofgem.gov.uk/publications-andupdates/social-action-plan-annual-review-2003> (last accessed 25 July 2018).

${ }^{28}$ Gas Act 1986, s.4AA (3); Electricity Act 1989, s.3A (3). 
While in the aftermath of privatisation prices for electricity and gas fell, from 2000 prices began to increase. By 2008, there was a major concern about the competitiveness of the industry. ${ }^{29}$ This led to a series of unsuccessful interventions, aimed at re-regulating the retail energy market that eventually culminated in the referral of the industry to the CMA for an in-depth market investigation in $2014 .^{30}$ This notoriously broad tool granted by the Enterprise Act 2002 enables the CMA to look at any competition issue connected with the supply or acquisition of gas and electricity in Great Britain, including both retail (households and microbusiness) and wholesale markets, so as to decide whether any existing market failures result in an adverse effect on competition (AEC) ${ }^{31}$ If one or more AECs are to be found, then the CMA must determine whether it should take action itself to remedy the AEC, and/or whether it should recommend actions to be taken by others (such as the government or the regulator). ${ }^{32} \mathrm{~A}$ broad range of remedies can be imposed, ranging from structural remedies (i.e. divesture), to licence modifications, price controls, informational remedies and recommended actions. ${ }^{33}$

After a two-year market investigation, the report focused on weak consumer response as one of the identified AEC, ${ }^{34}$ and introduced a narrow price cap to protect consumers on prepayment meters only, and not consumers on poor value tariffs, such as SVTs. To better appreciate the CMA's choice to impose a consumer protection rather than empowerment remedy, it is important to evaluate the price cap in light of Ofgem's prior interventions in the retail energy market and the unintended consequences thereof. These interventions were first, the non-discrimination obligations for energy suppliers adopted following the

\footnotetext{
${ }^{29}$ Ofgem, 'Ofgem launches probe into energy supply markets' (21 February 2008) available at: https://www.ofgem.gov.uk/publications-and-updates/ofgem-launches-probe-energy-supply-markets (last accessed 25 July 2018).

${ }^{30}$ See $n 9$.

${ }^{31}$ EA 2002, s 134(2). See generally on market studies, T. Indig and M.S. Gal, 'New Powers - New Vulnerabilities? A Critical Analysis of Market Inquiries Performed by Competition Authorities' in F. di Porto and J. Drexl (eds), Competition Law As Regulation (Cheltenham: Edward Elgar Publishing, 2015) and N. Dunne, 'Between Competition Law and Regulation: Hybritised Approaches to Market Control' (2014) 2(2) Journal of Antitrust Enforcement 225.

${ }^{32}$ EA, s. 134(4).

${ }^{33}$ EA, s. 161 and Schedule 8. See further, BAA Limited v Competition Commission [2009] CAT 35, para. 117.

${ }^{34}$ See n 9, para 154.
} 
Energy Supply Probe ${ }^{35}$ in 2009 and second, the simplification of tariffs introduced in light of the Retail Market Review initiated in 2010. ${ }^{36}$ Both had attracted wide criticism from the academic community at the time of their introduction and were scrutinised in great detail by the CMA. ${ }^{37}$

Regarding the non-discrimination obligations, these prevented energy suppliers from first, charging different prices in different regions, ${ }^{38}$ and second, from charging different prices for customer groups on different payment methods. ${ }^{39}$ The basis for the interventions was the protection of vulnerable consumers, given that these consumers were less likely to take advantage of new entrants' offers or benefit from better prices offered to direct debit customers. ${ }^{40}$ However, such interventionist measures created unintended consequences for consumer empowerment and the development of competition. ${ }^{41}$ Hence, during the second wave of interventions associated with the Retail Market Review, Ofgem removed such obligations and introduced instead measures aiming at the simplification of tariffs ('simpler choices' component). ${ }^{42}$ Tariff simplification was premised on the findings of behavioural economics regarding consumers' cognitive limits and aimed at facilitating consumer switching. ${ }^{43}$ However, it had the opposite effect on consumer engagement, as predicted by

\footnotetext{
35 Ofgem, 'Ofgem launches probe into energy supply markets' (21 February 2008) available at: https://www.ofgem.gov.uk/publications-and-updates/ofgem-launches-probe-energy-supply-markets (last accessed 30 July 2018).

36 Ofgem, 'Retail Market Review' (2010) available at: https://www.ofgem.gov.uk/electricity/retailmarket/market-review-and-reform/retail-market-review (last accessed 30 July 2018).

${ }^{37}$ S. Littlechild, 'The Competition Assessment Framework for the Retail Energy Sector: Some Concerns about the Proposed Interpretation' (2014) European Competition Journal 181, 191. Hviid and Waddams Price (n 24); S. Littlechild, 'Ofgem's Retail Choice: A Response to Ofgem's Consultation on SLC 25A' (28 May 2012), available at https://www.ofgem.gov.uk/ofgempublications/39485/25astephen-littlechildresponse.pdf. (last accessed 30 July 2018); C. Waddams Price and M. Zhu, 'Prices and Consumer Switching in the British Retail Electricity Market', Working Paper 13-12 (Centre for Competition Policy, 2013).

${ }^{38}$ Energy suppliers charged 10 per cent more to their existing customers thus exploiting customers' loyalty in their home markets.

${ }^{39}$ Payment methods include direct debit, standard credit and prepayment. Prepayment meters are installed, when customers have a poor payment record. See CMA, 'Energy Market Investigation - Summary of provisional findings Report' (7 July 2015), paras 92-94.

${ }^{40}$ Hviid and Waddams Price (n 24) 244.

${ }^{41}$ Ibid, 248.

${ }^{42}$ These measures included a ban on complex tariffs, a maximum limit on the tariffs offered and a simplification of cash discounts.

${ }^{43}$ In particular, framing bias can be exacerbated in an environment where consumers are presented with a lot of information. This information can be purposefully presented in a confusing manner creating the problem of confusopoly. On framing biases see A. Tversky \& D. Kahneman, 'The Framing of Decisions and the Psychology of Choice' (1981) SCIENCE 211. Confusopoly was first coined in S. Adams, The Dilbert Future (New York: Harper Collins, 1997). J. Mehta and R. Sugden, 'Making Sense of Complex Choice Situations'
} 
incumbents and new entrants; ${ }^{44}$ it restricted consumer choice, adversely impacted the competitive process and reduced consumer welfare. ${ }^{45}$ The upshot was that prices increased for all consumers.

Eventually, the regulator referred the energy market to the CMA, which adopted a range of remedies aiming at addressing the empowerment/ protection regulatory dilemma and enabling every consumer to reap the benefits of competition. Hence, the CMA's consumer empowerment measures included an Ofgem-controlled database of disengaged customers allowing suppliers to target consumers that have remained on poor value tariffs, such as SVTs, for more than three years as well as measures incentivising the roll-out of smart meters. ${ }^{46}$ Consumer protection measures were also put forward for the protection of vulnerable consumers. These included the imposition of a transitional price cap for customers on prepayment meters $(2017-2020) ;{ }^{47}$ prepayment meters being a proxy for vulnerability. The CMA cautioned against the introduction of a wider price cap on all SVTs, as such wide a price cap would stifle the competitive process and harm consumers in the long run. ${ }^{48} \mathrm{~A}$ dissenting view, however, expressed by the CMA panel member, Professor Martin Cave, argued that the proposed remedies did not go far enough:

[t]he harm which is presently inflicted on households in this market ( $£ 2$ billion in 2015 , or an average of $£ 75$ for every British household) is very severe, and in my opinion how far and how fast that harm is reduced is the key indicator of the success of the household market remedies. But the remedies proposed for the large majority of households will take some time to come into effect, and are in any case untried and untested. ${ }^{49}$

Highlighting the failure of a number of information remedies at empowering customers on SVTs - put forward since the Retail Market Review - Professor Cave proposed instead to supplement the consumer empowerment remedies with a price cap on SVTs. This would

in J. Mehta (ed), Behavioural Economics in Competition and Consumer Policy (2013) available at http://competitionpolicy.ac.uk/documents/8158338/8193541/CCP+economics+book+Final+digital+version +-+colour.pdf/30214557-cace-4b0b-8aac-a801bbde87bc (last accessed 15 July 2019$) 41$.

${ }^{44}$ State of the Market Assessment (n 24), paras 3.38-3.43.

${ }^{45}$ See $n 9$ above, paras 172-177.

${ }^{46}$ CMA, 'Energy Market Investigation - Summary of Final Report (24 June 2016) paras 224, 231-235.

${ }^{47}$ Ibid, paras 243-252.

${ }^{48}$ See $\mathrm{n} 9$, para 251.

${ }^{49} \mathrm{Ibid}, 1415$. 
apply for a temporary period of two years so as to remove a significant part of consumer detriment. ${ }^{50}$ The ensuing political debate about the appropriate policy interventions continued, fuelled further by the increasingly widening gap between prices paid by consumers who stay with their supplier and those who switch supplier. It is this debate that ultimately led to the UK Domestic Gas and Electricity (Tariff Cap) Act.

The various regulatory episodes to date, ranging from the non-discrimination clauses to the simplification of tariffs, and from the narrow price cap on prepayment meters to the wider price cap on SVTs, vividly exemplify the conundrum of balancing consumer empowerment and consumer protection measures. Against this background, the enactment of the Tariff Cap Act, with its largely protectionist undertone, is significant insofar as it signals a repudiation of the overarching $\mathrm{UK}$ and EU paradigm of consumer empowerment ${ }^{51}$ that has primarily informed the regulatory remedies to date. This paradigm, as it is reflected inter alia in the EU policy discourse, ${ }^{52}$ prioritises consumer empowerment rather than direct consumer protection measures, such as retail price regulation. However, as we argue below, the introduction of the price cap, notwithstanding its drafters' good intentions, is premised on an ill-informed understanding of the process of consumer empowerment and risks becoming yet another failed intervention in the retail energy market.

\footnotetext{
50 Ibid.

${ }^{51}$ See COM(2015), 'A Framework Strategy for a Resilient Energy Union with a Forward-Looking Climate Change Policy' (25 February 2015), at 11. COM(2015), 'Energy Union Package - Roadmap for the Energy Union', at 3; New Deal (n 14).

${ }^{52}$ COM(2007), 'EU Consumer Policy Strategy 2007-2013', at 5; COM(2011), 'Single Market Act-Twelve Levers to Boost Growth and Strengthen Confidence', para. 2.4. See Annex 1 of the Electricity Directive 2009/72/EC and Gas Directive 2009/73/EC. For an analysis see A. Johnston, 'Seeking the EU 'Consumer' in Services of General Economic Interest' in D. Leczykiewicz and S. Weatherill (eds), The Images of the Consumer in EU Law: Legislation, Free Movement and Competition Law (Oxford: Hart, 2016).
} 


\section{The Tariff Cap Act in Context}

This section will first situate the suggested price cap within the EU energy acquis so as to appreciate the scope and conditions governing state intervention in retail price setting, before examining the difficulties inherent in the implementation of the price cap.

\section{A. The Scope and Conditions of Retail Price Regulation under the EU Energy Acquis}

While not prohibited a priori and not per se illegal, price caps are strictly regulated by the EU energy acquis. This is because they represent the most radical departure from the principle of market-based retail energy price formation enshrined in the paradigm of competitive retail energy markets. Furthermore, unlike consumer empowerment measures that are informed by the principle of economic efficiency, price caps are a paradigmatic example of consumer protection measures informed by considerations of social solidarity ${ }^{53}$ and affordability.

Affordability is referred to in the EU energy acquis as one of the defining elements of services of general economic interest, such as energy supply. ${ }^{54}$ 'High levels of affordability' feature also in the new Protocol No 26 on Services of General Interest (inserted by the Treaty of Lisbon) among the 'shared values of the Union' in respect of services of general interest. ${ }^{55}$ Though affordability can be achieved via various instruments, not necessarily lying within the market context (such as tax exemptions or subsidies) the common denominator is that they all involve a departure from the purely economic rationales for public intervention in markets so as to achieve a socially, rather than economically desirable outcome. Such an outcome is reflected in the concept of an

\footnotetext{
${ }^{53}$ For a general account see C. Barnard, 'EU Citizenship and the Principle of Solidarity' in M. Dougan and E. Spaventa (eds), Social Welfare and EU Law (Oxford: OUP, 2005) 157. See further T. Prosser, 'Regulation and Social Solidarity' (2006) 33 (3) Journal of Law and Society 364 and E. Szyszczak, 'Public Service Provision in Competitive Markets' (2001) 20 (1) Yearbook of European Law (2001) 35.

54 The supply of energy has been listed as a SGEI. See Case C-393/92, Municipality of Almelo and Others, EU:C:1994:171, paras. 46-48 and Case C-159/94, Commission v France, EU:C:1997:501, para. 57.

55 Protocol No 26 on Services of General Interest, Art. 1.
} 
'affordable price'. Affordability necessitates, in principle, a departure from cost-reflective prices set by the market mechanism. ${ }^{56}$

Such departure, however, should be in line with the conditions of retail price regulation, as the latter have been developed by the Court of Justice of the European Union (CJEU). ${ }^{57}$ According to the CJEU, state intervention in retail price setting should be justified in the general economic interest ${ }^{58}$ and comply with the principle of proportionality ${ }^{59}$ In essence, proportionality entails that the intervention should not go beyond what is necessary to achieve the objective that is being pursued in the general economic interest and should be limited to the price component influenced by the specific circumstances, but not to the final end-users' price. ${ }^{60}$ Furthermore, the intervention should be transitory in nature, with limited duration, and subject to periodic re-examination at close intervals by the relevant regulatory authority. The CJEU has further stated that the 'requirement of proportionality must also be assessed with regard to the scope ratione personae of the measures and more particularly its beneficiaries' ${ }^{61}$ In other words, when assessing whether a specific national measure is proportionate, account has to be taken of differences between the position of undertakings and the position of household consumers and also of objective differences in size between the undertakings themselves. ${ }^{62}$ Finally intervention should be 'clearly defined, transparent, non-discriminatory and verifiable', as well as guaranteeing equal access for companies to consumers. ${ }^{63}$ This strict regulation of state intervention is reflected in the announced 'Winter Package'. In addition to the Commission's commitment to

\footnotetext{
${ }^{56}$ For a detailed analysis see D. Mantzari, 'The Quest for Reasonable Retail Energy Prices in Europe: Positive and Normative Dimensions' (2017) 36 (1) Yearbook of European Law 599, 609-610.

57 See e.g. Federutility (n 15), paras 18-19; Enel (n 15), Case C-36/14, Commission v Poland, EU:C:2015:570; Case C-121/15, Association nationale des operateurs detaillants en energie (ANODE) $v$ Premier ministre and Others, EU:C:2016:248. Following Brexit, Ofgem may resort more freely to retail price regulation. However, arguably, the conditions for state intervention set out in the CJEU's case law should still be given due regard before intervening in order to avoid unintended consequences. See I. Lianos, D. Mantzari, F. Wagner von Papp and F. Thepot, 'Brexit and Competition Law', Centre for Law, Economics and Society; Policy Paper Series n2/2017 (2017) para. 25 at < http://discovery.ucl.ac.uk/10045083/1/Lianos_cles-policy-paper-2-2017.pdf> (last accessed 12 September 2018).

${ }^{58}$ Federutility (n 15), para. 25.

${ }^{59}$ Ibid., paras 35, 38, 43.

${ }^{60}$ Ibid., para. 38.

${ }^{61}$ Ibid., para.39.

${ }^{62}$ Ibid., para. 42.

${ }^{63}$ Ibid., para. 47.
} 
completely phase out regulated prices in the new energy market design, most crucially, the Recast Directive on common rules for the internal market in electricity ${ }^{64}$ clearly stipulates that 'Member States should apply other policy tools, and in particular targeted social policy measures, to safeguard the affordability of electricity supply to their citizens ${ }^{96}$ with price regulation being applied 'in limited exceptional circumstances' ${ }^{66}$

Having briefly discussed the conditions and limits of retail price regulation, the following section will delve into the main provisions of the Tariff Cap Act and discuss the difficulties surrounding its implementation within the existing paradigm of competitive retail markets.

\section{B. Implementing the Tariff Cap Act}

The abovementioned EU regulatory framework governing retail price regulation is broadly reflected in the main provisions of the Tariff Cap Act. Echoing general economic interest and proportionality considerations, the Act requires Ofgem to modify the standard supply licence conditions in order to include 'tariff cap conditions' ${ }^{67}$ Such conditions impose a cap on existing and future consumers on standard variable and default rates. The tariff cap does not apply to consumers on prepayment meters, to vulnerable customers and the supply of 'green energy' produced from renewable sources. ${ }^{68}$ The first two categories of consumers already benefit from consumer protection measures, namely a price cap imposed by a CMA order ${ }^{69}$ and the Warm Home Discount. ${ }^{70}$

Notwithstanding, however, its compatibility with EU law, the implementation of the price cap still represents a truly daunting task. According to section 1 (6) of the Tariff Cap Act, in setting the price cap, Ofgem:

\footnotetext{
${ }^{64} \operatorname{COM}(2016)$, 'Proposal for a Directive of the European Parliament and of the Council on common rules for the internal market in electricity' (Brussels, 30 November 2016).

${ }^{65}$ Ibid Recital 14.

${ }^{66}$ Ibid. Recital 14; Art. 5(2)-(4).

${ }^{67}$ Section 1(1) Tariff Cap Act.

${ }^{68}$ Sections 3(1) and (2) Tariff Cap Act.

69 CMA, 'The Energy Market Investigation (Prepayment Charge Restriction) Order 2016' $<$ https://assets.publishing.service.gov.uk/media/5847e1bfed915d0b1200004f/energy-market-prepaymentcharge-restriction-order-2016.pdf > (last accessed 20 July 2018).

${ }^{70}$ See Ofgem, 'Safeguard tariff (or 'price cap')' $<$ https://www.ofgem.gov.uk/gas/retail-market/marketreview-and-reform/implementation-cma-remedies/safeguard-tariff-or-price-cap > (last accessed 20 July 2018). This scheme provides a $£ 140$ discount to energy bills for customers meeting certain criteria. See text to $n$ above.
} 
'must have regard to the following matters:

(a) the need to create incentives for holders of supply licences to improve their efficiency;

(b) the need to set the cap at a level that enables holders of supply licences to compete effectively for domestic supply contracts;

(c) the need to maintain incentives for domestic customers to switch to different domestic supply contracts;

(d) the need to ensure that holders of supply licences who operate efficiently are able to finance activities authorised by the licence'.

In other words, the regulator has to strike the balance between the divergent interests of suppliers, new entrants and ultimately consumers. This requires the price cap to be set at such a level that can abolish exploitative SVTs and default tariffs, while simultaneously preserving energy suppliers' incentives to compete, new entrants' incentives and consumers' incentives to switch. If, on the one hand, the price cap is set too low, it will chill both consumers' incentives to switch and suppliers' incentives to innovate and offer lower tariffs. If, on the other hand, the price cap is set too high, while preserving consumers' incentives to switch, it will nonetheless risk defeating its purpose, that of eliminating poor value tariffs. For example, in 2016 switching saw a six-year high, whereas the number of energy suppliers has more than tripled in the last five years (from 14 to approximately 50). ${ }^{71}$ If this is the case, a price cap set at a wrong level risks delivering suboptimal outcomes.

It is these insurmountable, at times, difficulties of 'getting the price cap right' that have contributed to price regulation being a much-disputed enterprise in contemporary regulatory practice. ${ }^{72}$ At the core of the complex balancing exercise lies the methodology used for the calculation of the price cap. To this effect, Ofgem carried out a consultation

\footnotetext{
71 N. Barnes, 'Why Energy Consumers are Voting with their Feet?' (27 February 2017) available at https://www.ofgem.gov.uk/news-blog/our-blog/why-energy-consumers-are-voting-theirfeet?utm_medium=email\&utm_source=dotMailer\&utm_campaign=Daily-Alert 27-022017\&utm content=Why\%20energy\%20consumers\%20are\%20voting\%20with\%20their\%20feet\&dm i=1 QCB,4SK5O,F31C77,I1M3X,1 (last accessed 20 July 2018).

${ }^{72}$ For lessons drawn from (failed) attempts to introduce price regulation see J. Sweeney, The California Electricity Crisis (USA: Hoover Institution Press, 2002).
} 
on the methodology to be adopted before the introduction of the price cap. ${ }^{73}$ This earlier consultation remains valid and can potentially inform the final methodology to be adopted after the Act has come into effect. ${ }^{74}$ It also signals the government's intention to implement the price cap as soon as possible and no later than winter 2018/2019. ${ }^{75}$ Ofgem proposed the price cap on $6^{\text {th }}$ September 2018 and aims to confirm the cap level in November $2018 .^{76}$ The price cap is set at $£ 1136$ annually for a dual fuel customer paying by direct debit. Consumer savings will depend on the level of their default tariff and their energy consumption, though it is estimated that consumers will save around $£ 75$ on average which falls short of the $£ 100$ promised by the government. ${ }^{77}$

Reflecting again the conditions laid down by EU law, the adopted price cap is meant to be temporary only and will be reviewed at first instance in 2020, with a view of assessing whether 'the conditions are in place for effective competition for domestic supply contracts' ${ }^{78}$ Following the review, if the Secretary of State concludes that such conditions are not in place, the price cap can be extended by another year and then reviewed again. This process can be repeated, with price caps ceasing to have effect at the end of 2023 at the latest. ${ }^{79}$

Leaving aside the challenges inherent in 'getting the price cap right', its imposition is also problematic when one is reminded of the primary underlying rationale of such drastic intervention: that of addressing consumer disengagement with the market as a means to ensure affordable energy prices. The price cap, however, is blind to the underlying reasons for such disengagement. For example, is lack of switching owing to consumer inertia and/or does it signal consumer vulnerability? If the former is true, is it appropriate to promote 'equality of outcome' through the imposition of an absolute price cap or should the focus of regulatory interventions be on promoting the equal opportunity to participate

73 Ofgem, 'Default Tariff Cap: Policy Consultation Overview document' (25 May 2018) $<$ https://www.ofgem.gov.uk/system/files/docs/2018/05/default_tariff_cap_-_policy_consultation_overview.pdf > (last accessed 20 July 2018).

${ }^{74}$ Section 2 (4) Price Cap Act.

${ }^{75}$ Ofgem Consultation (n 73) para.1.8.

${ }^{76}$ Ofgem, 'Ofgem Proposes Price Cap to Give 11 Million Customers a Fairer Deal for their Energy' (6 September 2018) available at <https://www.ofgem.gov.uk/publications-and-updates/ofgem-proposes-pricecap-give-11-million-customers-fairer-deal-their-energy> (last accessed 12 September 2018).

${ }^{77}$ Ibid.

${ }^{78}$ Section 7 Price Cap Act.

${ }^{79}$ Section 8 Price Cap Act. 
in the retail market through strengthening consumer empowerment? The Price Cap Act, however, is solely informed by the outcome of consumer empowerment, the rate of switching and disregards, as we shall see below, consumer empowerment as a process. 


\section{Price Caps: An One size Fits all Solution to Consumer Disengagement from the Market?}

Psychology and marketing literature have highlighted that empowerment incorporates both the process of enhancing consumers' capabilities as well as the identifiable outcome of such process. ${ }^{80}$ In the liberalised retail energy market, empowerment as a process is premised on the provision of information and is directly associated with a measurable outcome, namely the act of switching. It, therefore, comprises the following two steps. First, providing access to the relevant information and aiding consumers in the assessment of such information, and second, consumers acting upon such information, i.e. the outcome of empowerment. It naturally follows that lack of action, in this case switching, can be attributed to problems in the process. However, we submit here that this is not the only plausible explanation. Consumer disengagement with the market may be owing to various other reasons that relate to the multiple consumer images and the multifaceted nature of consumer vulnerability. A better appreciation of the underlying reasons for consumer disengagement with the market will more clearly reveal the limits of price cap regulation in remedying such disengagement.

\section{A. The Multiple Consumer Images}

In addressing consumer disengagement with the market, the price cap seems to have been informed by an overtly simplistic distinction between an 'active' consumer and a 'vulnerable' consumer. Such binary an approach disregards, however, other consumer images, such as the 'active engaged' and 'passive engaged' that are also relevant to consumer empowerment as a process. An 'active engaged' consumer has access to relevant information, the ability to assess it and act upon it. ${ }^{81}$ In contrast, a 'passive engaged'

\footnotetext{
${ }^{80}$ D. Perkins and M. Zimmerman, 'Empowerment Theory, Research and Application' (1995) 23 American Journal of Community Psychology 569; M. Zimmerman, 'Psychological Empowerment: Issues and Illustrations' (1995) 23 American Journal of Community Psychology 581; J. Denegri-Knott, D. Zwick and J. Schroeder, 'Mapping Consumer Power: An Integrative Framework for Marketing and Consumer Research' (2006) 40 European Journal of Marketing 950.

${ }^{81}$ See OFT 1224, 'What does Behavioural Economics Mean for Competition Policy?' (March 2010), 10-11. This is referred to as the OFT 'Access, Assess, Act' Framework. See Ofgem, 'What can behavioural
} 
consumer is the consumer who enjoys the ability to access and assess the information, but chooses not to act. To these images one could also add that of the 'passive empowered' consumer, who chooses not to switch because, for example, she is satisfied with the current supplier, ${ }^{82}$ or consciously accepts to pay a higher price in order to avoid loss of time and switching costs. An appreciation of these different consumer images is crucial insofar as lack of action on the information provided does not necessarily imply a failure in the process of empowerment. It, thus, may not necessarily invite consumer protection measures, such as the price cap, but consumer empowerment measures.

In cases, however, where it does indeed indicate a failure in the process of empowerment, care must be taken in identifying the underlying causes. These can be summarised in the concept of consumer vulnerability and its multifaceted nature. Regrettably, as the following section will demonstrate, the suggested price cap seems to have adopted a monolithic view of consumer vulnerability and ignores the potential of 'empowerment as a process' to phase out certain vulnerabilities without the need of direct regulatory intervention.

\section{B. The Multifaceted Nature of Consumer Vulnerabilities and its Implication for Regulatory Intervention}

Norbert Reich's typology of consumer vulnerability serves well our purposes here. ${ }^{83}$ According to Reich, vulnerability comes in three different forms: i) physical disability; ii) intellectual disability and iii) economic disability. ${ }^{84}$ Furthermore, as highlighted by Ofgem, vulnerability should be understood as a rather fluid and transient state, as every consumer can be potentially vulnerable at a given time in her life. ${ }^{85}$ Likewise, the European Commission (Commission) has also accepted that vulnerability is not static and comprises

economics say about GB energy consumers?' (21 March 2011). 'State of the Market Assessment' (n 24) para. 3.1; CC3 (Revised), 'Guidelines for market investigations: Their role, procedures, assessment and remedies’ (April 2013) para. 296.

${ }^{82}$ ACER/ CEER, 'Annual Report on the Results of Monitoring the Internal Electricity and Natural Gas Markets in 2014' (November 2015) (ACER/ CEER 2014), 97.

${ }^{83}$ N. Reich, 'Vulnerable Consumers in EU Law', in D. Leczykiewicz and S. Weatherill (Eds), The Images of the Consumer in EU Law: Legislation, Free Movement and Competition Law (Oxford: Hart, 2016) 141.

${ }^{84}$ Ibid.

${ }^{85}$ Ofgem, 'Consumer Vulnerability Strategy' (4 July 2013). See further FCA, 'Consumer Vulnerability' (February 2015) (Occasional Paper No 8). FCA, 'Applying Behavioural Economics at the Financial Conduct Authority' (April 2013 - Occasional paper No 1) 32. 
consumers' personal characteristics and capabilities as well as conditions pertaining to the specific market situation. ${ }^{86}$ Both personal and market vulnerabilities impact on consumers' ability to engage with the market and exercise empowerment, yet their drivers are different and may call for different forms of intervention. Each face of vulnerability will be explained in turn along with its implications for the type of regulatory intervention, not necessarily exhausted to retail price regulation.

While physical disability is quite self-explanatory, intellectual disability is far more complex. Reich employs Griggs' definition which regards as intellectually disabled 'those persons who have limited rights and resources to exercise the range of choices possible in a given consumer market. ${ }^{87}$ That can otherwise be referred to as market vulnerabilities, that is difficulties 'cop[ing] with the requirements of the modern consumer society'. ${ }^{88}$ For example, it may relate to difficulties in gathering and processing information and gaining access to advice and support. Such barriers to consumer empowerment may make it, in turn, difficult for consumers to find energy contracts best suited to their situation, or may lead to exclusion from technological innovations, such as the development of smart meters, smart grids, and demand response programs. ${ }^{89}$

Indeed, mounting evidence suggests that consumers rarely conform to the model of selfinterested utility maximisation inherent in the neoclassical economics paradigm that has informed the original regulatory framework of privatised UK industries, ${ }^{90}$ because of a number of biases which impede rational choice. ${ }^{91}$ Some of these biases are relevant in the

\footnotetext{
${ }^{86}$ Commission (EU), 'Consumer Vulnerability Across Key Markets in the European Union - Final report' (January 2016), Executive Summary xviii.

${ }^{87}$ L. Griggs, 'The Consumer with an Intellectual Disability-Do We Respond, if so, How?', in: N. Reich, "Vulnerable Consumers in EU Law" (n 83).

${ }^{88}$ H. Micklitz, 'Universal Services: Nucleus for a Social European Private Law' in M. Cremona (ed), Market Investigation and Public Services in the European Union (Oxford: OUP, 2011) ch. 3, p.21.

${ }^{89}$ For an empirical assessment see M. Fernández- Gutiérrez et al, 'Competition and Switching in Public Service Markets: Can They Reduce Inequalities?'(2017) 11(1) Journal of Regulation and Governance 41.

${ }^{90}$ See C. Mc Fadden, 'Free Markets and Fettered Consumers' (2006) 96 (1) American Economics Review 3; C. Waddams Price and M. Zhu, 'Empirical Evidence of Consumer Response in Regulated Markets' (2016) 12 (1) Journal of Competition Law and Economics 113-149; S. Lavrijssen, 'The Different Faces of Energy Consumers: Toward a Behavioral Economics Approach' (2014) 10 (2) Journal of Competition Law and Economics 257.

${ }^{91}$ See, for example, A. Tversky and D. Kahneman, 'Judgment Under Uncertainty: Heuristics and Biases' (1974) 185 Science 1124; C. Jolls et al, 'A Behavioral Approach to Law and Economics' (1998) 50 Stanford Law Review 1471; D. Ariely, 'Controlling the Information Flow: Effects on Consumers' Decision Making and Preferences' (2000) 27 Journal of Consumer Research 233; R. Thaler and C. Sunstein, Nudge: Improving
} 
context of retail energy markets and are exploited by energy suppliers, as the CMA energy market investigation illustrated. For example, empirical research suggests that consumers tend to have a preference for the status quo. ${ }^{92}$ Such behaviour, otherwise known as 'loss aversion' or 'status quo bias', is brought up to explain situations whereby consumers fail to investigate alternative energy contracts that may be more beneficial to them. 'Framing bias', on the other hand, describes the situation where the framing of the information can induce consumers to act accordingly. ${ }^{93}$

Measures to overcome such biases are present in both the EU and UK and include the provision of clear and user-friendly information about consumer rights, especially the right to switch supplier, the content of the supply contracts and their energy consumption. Regarding the latter, smart meters are in the process of being rolled out for more accurate metering that combined with price comparison tools can facilitate switching. ${ }^{94}$ Price comparison tools have also increased in popularity as a means for enabling consumers to find and switch to the most appropriate tariff. In addition to individual consumers switching supplier, collective switching schemes can also be used to reduce the energy bill for groups of consumers. Measures aiming at phasing out consumer biases can contribute to progressively improving consumers' intellectual disability or market vulnerability. Regulators have been increasingly aware of the limits of consumer rationality, reflected in consumer vulnerabilities owing to the latter. Hence, regulatory focus in the UK has gradually shifted from an effort to control market power and the prices offered to consumers to appreciating and - as the return to price cap suggests - even controlling the ways in which 'behavioural' consumers respond to these offers.

Intellectual, or market vulnerability, however, does not necessarily instruct an interventionist approach. This is corroborated by the previous interventions in retail energy markets, discussed in Section II above, which were influenced by a short-term approach to empowerment. To the contrary, rather than advocating such a short-term approach to

Decisions about Health, Wealth and Happiness (New Haven, Yale University Press, 2008); See also OFT 1324, 'Consumer Behavioural Biases in Competition: a Survey' (Final Report) (May 2011). Behavioural Insights Team, 'Applying Behavioural Insights to Regulated Markets' (26 May 2016).

${ }^{92}$ M. Pollitt and I. Shaorshadze, 'The Role of Behavioral Economics in Energy and Climate Policy', ESRC Electricity Policy Research Group (Cambridge 2011).

${ }^{93}$ See (n 43) above.

${ }^{94}$ New Deal (n 14), 3-5. 
empowerment through measures aimed at triggering switching, regulators should better appreciate the underlying reasons of consumers' disengagement from the market. This presupposes a better understanding of both the image of 'passive empowered' consumers and what it entails as well as the long-term nature of consumer empowerment. A step towards this direction is the work already undertaken by the UK Regulators Network (UKRN). The UKRN was established in 2014 and provides the forum for regulators to consider common issues and policy projects with relevance across utility, financial and transport sectors. A distinct area of concern is the effective sharing of non-financial vulnerability data among regulated companies in the energy and water sectors so as to identify consumers in vulnerable situations and better understand the various drivers of consumer vulnerability. ${ }^{95}$ Understanding the multifaceted nature of consumer vulnerability in such an integrated manner is crucial for the adoption of a long-term approach to empowerment. It further has the potential to better address and remedy vulnerabilities pertaining to the market context, such as intellectual disabilities. Furthermore, for the empowerment measures to deliver their potential, the process of empowerment needs to be nurtured rather than meddled with. Measures such as the suggested price cap can further exacerbate consumers' inertia and dis-incentivises them from engaging with the market in search for better deals.

Finally, the third form of vulnerability, that of economic disability, may stem from the difficult economic situation of the consumer and relate to unemployment, illness and other unforeseen circumstances. ${ }^{96}$ These situations represent examples of personal vulnerabilities, where either consumers lack the ability to access and assess the information or cannot act upon it. These vulnerabilities, we argue, need to be addressed by social policy measures. Another example of personal vulnerability is that of energy poverty. Energy poverty, is linked to low income only and has been defined as the inability of consumers to heat their homes or enjoy other energy services at an affordable cost. ${ }^{97}$ One indicator is the expenditure on energy compared to the household income. In the UK, a household is

\footnotetext{
${ }^{95}$ UKRN, 'Making Better Use of Data: Identifying Customers in Vulnerable Situations: A Report for Water and Energy Companies' (2017) available at: http://www.ukrn.org.uk/wp-content/uploads/2017/10/Makingbetter-use-of-data-identifying-customers-in-vulnerable-situations.pdf (last accessed 12 September 2018).

${ }^{96}$ Reich (n 83) 144.

${ }^{97}$ See ACER and Trinomics (2016), 'Selecting Indicators to Measure Energy Poverty'.
} 
in fuel poverty, where more than 10 per cent of its income is spent on energy. ${ }^{98}$ Thus, energy poverty concerns affordability, and may invite a more long-term preventive approach, not always lying within the market context. In sum, while intellectual disability (or market vulnerability) can be remedied by resorting to consumer empowerment measures, the situation is radically different in the face of personal vulnerabilities. Poor consumers, or chronically ill, necessitate consumer protection measures rather than empowerment measures. In other words, consumer empowerment and the competitive process reach their respective limits in the presence of such extreme personal vulnerabilities. Such protection measures should be implemented outside the market context and in a targeted manner, through for example, social welfare measures or energy efficiency measures, so as to not distort the competitive process. The legal basis for such measures is to be found in Article 3(8) of the Electricity Directive 2009/72/EC:

Member States shall take appropriate measures, such as formulating national energy action plans, providing benefits in social security systems to ensure the necessary electricity supply to vulnerable customers, or providing for support for energy efficiency improvements, to address energy poverty where identified, including in the broader context of poverty. Such measures shall not impede the effective opening of the market set out in Article 33 or market functioning and shall be notified to the Commission, where relevant, in accordance with the provisions of paragraph 15 of this Article. Such notification may also include measures taken within the general social security system. ${ }^{99}$

Other targeted measures addressing economic disability involve financial interventions through the social welfare system. ${ }^{100}$ These may be necessary where a high percentage of disposable income is needed to cover energy costs, or to address the needs of retired and unemployed. Such interventions may include social benefits, tax exemption (based on, for example, income or the geographical location of the beneficiaries) and direct payments.

\footnotetext{
${ }^{98}$ See DECC, 'Annual Report on Fuel Poverty - Statistics 2013' (May 2013) 8; BEIS, 'Modernising Consumer Markets - Consumer Green Paper' (April 2018), para. 42.

${ }^{99}$ See also Art. 3(4) of the Gas Directive 2009/73/EC.

${ }^{100}$ See e.g. Austria's Electricity Assistance fund, discussed in the Vulnerable Consumer Working Group Guidance Document on Vulnerable Consumers (November 2013) available at: <https://ec.europa.eu/energy/sites/ener/files/documents/20140106_vulnerable_consumer_report_0.pdf〉 (last accessed 30 July 2018).
} 
Tax schemes in particular, such as different energy taxes or exemptions, should however be compatible with state aid rules, as should subsidies.

Economic and/or physical disability may be also addressed through price regulation, in the form of social tariffs, ensuring that vulnerable consumers can access the most affordable energy. ${ }^{101}$ A number of Member States has implemented such social tariffs. One option is to offer progressive tariffs whereby the more energy a consumer uses, the higher the tariff he pays. Alternatively some Member States offer lower tariffs for consumers who have a high-energy requirement. ${ }^{102}$

Against this backdrop, the suggested price cap fails to distinguish between the poor or economically vulnerable consumers and extends protection to every disengaged consumer, irrespective of whether she is vulnerable or not. It therefore a reflects 'a one size fits all' approach to consumer disengagement with the market that risks sacrificing 'empowerment as a process' as a mechanism for progressively facing out market or intellectual vulnerabilities.

\section{Conclusions}

There is little doubt that the return to price cap regulation in the UK retail energy market reflects an acknowledgment of the failure of the neoclassical economics, competition paradigm in the UK energy market. It, further, starkly exposes the limits of consumer rationality, upon which this original paradigm was predicated and heralds a new era of reregulating the retail energy market by resorting to consumer protection measures.

Our intention here was not, however, to advocate or advance a different paradigm that should govern the provision of essential services, such as energy supply. Our ambition was much narrower and critical: to highlight the difficulties inherent in reconciling price caps - both practically and conceptually - with the competitive process and consumer empowerment; the building blocks of the existing paradigm. Regulated prices impede the development of retail competition and can prevent market entry from new suppliers thus

\footnotetext{
${ }^{101}$ To this respect see Greece's social household tariff, Italy's social tariff for low-income families, Hungary's discount for large families discussed in the Vulnerable Consumer Working Group, n 100 above. ${ }^{102}$ Ibid.
} 
reducing consumer choice. Furthermore, artificially low retail prices prompt consumers to disengage from the market, and negatively impact the consumers' propensity to switch. Echoing such concerns, in the 'Energy Union' communication, the European Commission identified regulated retail prices as an obstacle to demand-side participation and retail competition. ${ }^{103}$

The argument is not that price caps are undesirable per se. The aim here is rather to criticise their suitability and effectiveness in addressing consumer disengagement with the market. An understanding of the underlying causes of such disengagement is at the heart of delineating the relevance and scope of such an interventionist measure. The implementation of the price cap has been blind to such an assessment. By distinguishing between the various consumer images and the various faces of consumer vulnerability, the article brought into greater focus the heterogeneous causes of consumer disengagement with the market. It further brought into the fore various other instruments that can render affordable energy prices, not necessarily exhausted in retail price regulation and without always sacrificing empowerment as a process. It remains to be seen whether our increasing understanding of the limits of consumer rationality will lead to a paradigm shift in the energy market and subsequently to a re-conceptualisation of the responsibility that energy suppliers ought to bear towards consumers.

$103 \operatorname{COM}(2015)$, 'Communication from the Commission to the European Parliament, the Council, the European Economic and Social Committee of the Regions and the European Investment Bank, A Framework for a Resilient Energy Union with a Forward-Looking Climate Change Policy', at 2.2. 